\title{
Effective thermal conductivity of the hair coat of Holstein cows in a tropical environment ${ }^{1}$
}

\section{Alex Sandro Campos Maia², Roberto Gomes da Silva ${ }^{3}$, João Batista Freire de Souza Junior², Rosiane Batista da Silva ${ }^{2}$, Hérica Girlane Tertulino Domingos ${ }^{2}$}

\footnotetext{
${ }^{1}$ Pesquisa financiada pela Fundação de Amparo à Pesquisa do Estado de São Paulo (FAPESP).

2 Laboratório de Biometereologia e Bem-Estar Animal, Núcleo de Biometereologia e Bem-Estar Animal (NUBBEA - http://www2. ufersa.edu.br/ portal/laboratorios/nubbea), Departamento de Ciências Animais, Universidade Federal Rural do Semi-Árido (UFERSA), CEP: 59625-900 Mossoró, RN.

${ }^{3}$ Laboratório de Biometeorologia e Bem-Estar Animal, Programa de Pós-Graduação em Ciência Animal, Universidade Federal Rural do Semi-Árido (UFERSA), CEP: 59625-900, Mossoró, RN.
}

\begin{abstract}
The objective of the present study was to assess the effective thermal conductivity of the hair coat $\left(\mathrm{k}_{\mathrm{ef}}, \mathrm{mW} \cdot \mathrm{m}^{-1} \cdot \mathrm{K}^{-1}\right)$ of Holstein cows in a tropical environment, as related to conduction and radiation in the absence of free convection. The average $\mathrm{k}_{\mathrm{ef}}$ was $49.72 \mathrm{~mW} \cdot \mathrm{m}^{-1} \cdot \mathrm{K}^{-1}$, about twice the conductivity of the air $\left(26 \mathrm{~mW} \cdot \mathrm{m}^{-1} \cdot \mathrm{K}^{-1}\right)$ and much less than that of the hair fibres $\left(260 \mathrm{~mW} \cdot \mathrm{m}^{-1} \cdot \mathrm{K}^{-1}\right)$. The low $\mathrm{k}_{\mathrm{ef}}$ values were attributed mainly to the small cross area of individual hairs, $\rho_{\text {ef }} / \rho_{\mathrm{f}}(17.2 \%$ and $21.3 \%$ for black and white hairs, respectively). White coats were denser, with longer hairs and significantly higher $\mathrm{k}_{\mathrm{ef}}\left(53.15 \mathrm{~mW} \cdot \mathrm{m}^{-1} \cdot \mathrm{K}^{-1}\right)$ than that of the black hairs $\left(49.25 \mathrm{~mW} \cdot \mathrm{m}^{-1} \cdot \mathrm{K}^{-1}\right)$. The heritability coefficient of the effective thermal conductivity was calculated as $h^{2}=0.18$ the possibility was discussed of selecting cattle for increased heat transfer through the hair coat.
\end{abstract}

Key Words: hair coat, Holstein cows, thermal conductivity

\section{Condutividade térmica efetiva da capa de pelame de vacas Holandesas em ambiente tropical}

RESUMO - O objetivo neste trabalho foi estudar a condutividade térmica efetiva do pelame $\left(\mathrm{k}_{\mathrm{ef}}, \mathrm{mW} \cdot \mathrm{m}^{-1} \cdot \mathrm{K}^{-1}\right)$ atribuída à condução e radiação na ausência de convecção livre no pelame de vacas Holandesas manejadas em ambiente tropical. A média para condutividade térmica efetiva do pelame foi $49,72 \mathrm{~mW} \cdot \mathrm{m}^{-1} \cdot \mathrm{K}^{-1}$, quase o dobro da condutividade térmica do ar (26 mW.m $\left.{ }^{-1} \cdot \mathrm{K}^{-1}\right)$ e bem inferior à do pelo $\left(260 \mathrm{~mW} \cdot \mathrm{m}^{-1} \cdot \mathrm{K}^{-1}\right)$. O baixo valor observado para condutividade térmica efetiva do pelame deve-se principalmente à pequena área ocupada por pelos $\left(\rho_{\mathrm{ef}} / \rho_{\mathrm{f}}\right)$, que foi somente $17,2 \%$ e $21,3 \%$ nos pelames preto e branco, respectivamente. O pelame branco foi mais denso e formado por pelos mais compridos, logo sua condutividade térmica efetiva $\left(53,15 \mathrm{~mW} \cdot \mathrm{m}^{-1} \cdot \mathrm{K}^{-1}\right)$ foi significativamente maior que a do pelame preto $\left(49,25 \mathrm{~mW} \cdot \mathrm{m}^{-1} \cdot \mathrm{K}^{-1}\right)$. A herdabilidade para a condutividade térmica efetiva é de 0,18 , o que indica a possibilidade de se fazer seleção para elevar a transferência de calor através da capa.

Palavras-chave: condutividade térmica, pelame, vacas Holandesas

\section{Introduction}

The thermal conductivity of hair coat is related to the structure of a non-homogeneous system (Davis \& Birkebak, 1974; Cena \& Monteith, 1975ab) constituted by the hairs and the air trapped among them. The metabolic heat generated in the inner body regions is conducted through the hair coat to the atmosphere (a) by free convection in the air among the hairs, and (b) by molecular conduction along the hairs (Davis \& Birkebak, 1974).
Evaluation of the thermal conductivity of hair coats is difficult because of the complexity of the energy transfer mechanism, as a result of the interacting convection, conduction and radiation processes within the hair coat (Kowalski, 1978). In order to understand the thermal conductivity in the non-homogeneous system constituted by hairs and air, Davis \& Birkebak, (1974) studied some coat characteristics that affect conductivity and observed that the coat thickness and position, size, diameter and number of hairs are mutually related traits 
which directly affect the thermal conductivity of the coat.

Based on the studies by Davis \& Birkebak (1974) and Cena \& Monteith (1975b) several models were developed to describe the effective thermal conductivity of the hair coat as a function of the coat characteristics (Kowalski, 1978). However, such models have been used to obtain thermal conductivity estimates based on the physical characteristics of reduced hair samples (Gebremedhin et al., 1983; 1997; Jiang et al., 2005), most of them taken from dead animals.

The objective of the present study was to estimate the effective thermal conductivity of the hair coat of Holstein cows in a tropical environment, using the models by Davis \& Birkebak (1974), Cena \& Monteith (1975b) and Kowalski (1978), taking into consideration the conduction and radiation processes in the absence of free convection. In addition, the genetic parameters of this trait were estimated, in order to assess the possibility of genetic improvement of the animals for tolerance to the tropical conditions.

\section{Material and Methods}

Hair samples were taken from the flank area about $20 \mathrm{~cm}$ below the spinal column, by means of adapted pliers, according to the method described by Silva (2000); 973 Holstein heifers and cows were sampled in a commercial herd in Descalvado, São Paulo (22 $01^{\circ}$ latitude, $47^{\circ} 53^{\prime}$ longitude, $856 \mathrm{~m}$ altitude); these animals were aged from 2 to 13 years and were offspring of 793 dams and 205 sires.

Coat thickness $(E, \mathrm{~cm})$ was measured in situ by means of a metal ruler. Average hair length $(C, \mathrm{~cm})$ was given as the mean length of the longest ten hairs of each sample, as chosen visually and measured with a digital calliper, according to the method by Udo (1978). The same ten hairs were measured for their diameters $(D, \mathrm{~cm})$ with a digital micrometer (Mitutoyo). The number of hairs per unit area $\left(N\right.$, hairs per $\left.\mathrm{cm}^{2}\right)$ was estimated by counting all the hairs of each sample and relating them to a skin area of $0.14 \mathrm{~cm}^{2}$; the estimate was later adjusted for $1 \mathrm{~cm}^{2}$.

The effective thermal conductivity of the coat $\left(\mathrm{k}_{\mathrm{ef}}\right.$, $\mathrm{mW} \cdot \mathrm{m}^{-1} \cdot \mathrm{K}^{-1}$ ) was calculated by assuming absence of air movements, according the system of Cartesian coordinates illustrated in Figure 1 (Davis \& Birkebak, 1974). The x axis is parallel to the skin and oriented to the predominant hair direction, while the $\mathrm{y}$ axis is normal to the skin. The $\mathrm{z}$ axis is normal to both $\mathrm{x}$ and $\mathrm{y}$; $\theta$ is the angle between $\mathrm{y}$ and the hair axis; $\theta_{\mathrm{f}}$ is the angle of the hair in relation to the normal to the skin; $\phi$ is the angle between $\mathrm{x}$ and the hair dominant

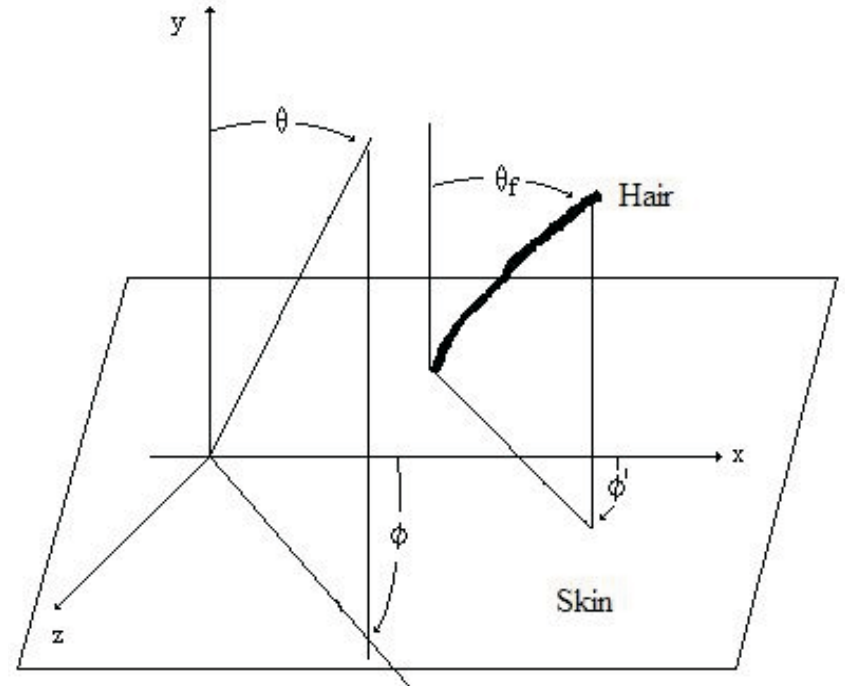

Figure 1 - Hair geometry: $\theta_{\mathrm{f}}=$ angle of the hair in relation to the normal to the skin; $\phi^{\prime}=$ angle between the hair projection on the sin and the hair dominant direction. Adapted from Davis \& Birkebak (1974).

direction; $\phi^{\prime}$ is the angle between the hair projection on the skin and the hair dominant direction.

According to Davis \& Birkebak, (1974) one needs only to calculate the energy flux in the y direction, in order to obtain $\mathrm{k}_{\mathrm{ef}}$ by means of the equation:

$$
\mathrm{k}_{\mathrm{ef}}=\mathrm{k}_{1} \cos ^{2} \theta_{\mathrm{f}}+\mathrm{k}_{\mathrm{p}} \operatorname{sen}^{2} \theta_{\mathrm{f}}
$$

For convenience,

$$
\mathrm{k}_{1}=\left\{\left[\frac{\rho_{\mathrm{ef}}}{\rho_{\mathrm{p}}}\right] \mathrm{k}_{\mathrm{f}}+\left[1-\left(\frac{\rho_{\mathrm{ef}}}{\rho_{\mathrm{f}}}\right) \mathrm{k}_{\mathrm{a}}\right]\right\}
$$

where $\mathrm{k}_{\mathrm{f}}$ and $\mathrm{k}_{\mathrm{a}}$ were thermal conductivities of the hairs and the air, respectively. According to Davis \& Birkebak (1974): $\mathrm{k}_{\mathrm{f}}=0.26 \mathrm{~W} \cdot \mathrm{m}^{-1} \cdot \mathrm{K}^{-1}$ and $\mathrm{k}_{\mathrm{a}}=0.025 \mathrm{~W} \cdot \mathrm{m}^{-1} \cdot \mathrm{K}^{-1}$.

Equation 1 demands knowledge of the fraction area parallel to the skin and the fraction volume of the coat that is effectively occupied by hair mass, at a given distance from the skin. Such a relation is:

$$
\frac{\rho_{\mathrm{ef}}}{\rho_{\mathrm{f}}}=\left(\frac{0,25 N \pi D^{2}}{\cos \theta_{\mathrm{f}}}\right)
$$

where $\theta_{\mathrm{f}}$ (decimal degrees) is the angle of the hairs in relation to the normal to the skin,

$$
\theta_{\mathrm{f}}=\arccos \left(\frac{E}{C}\right)
$$

Thus,

$$
\frac{\rho_{\mathrm{ef}}}{\rho_{\mathrm{f}}}=\frac{0,25 C N \pi D^{2}}{E}
$$


Thermal conductivity in a direction perpendicular to the hair axis $\left(\mathrm{k}_{\mathrm{p}} \mathrm{mW} \cdot \mathrm{m}^{-1} \cdot \mathrm{K}^{-1}\right)$ can be estimated according to Kowalski (1978) and Gebremedhin et al. (1997) in the following form:

$$
\mathrm{k}_{\mathrm{p}}=\left(\frac{\mathrm{k}_{\mathrm{a}}\left(l_{c}-D\right)}{l_{c}}\right)+\left(\frac{D \mathrm{k}_{\mathrm{a}} \mathrm{k}_{\mathrm{f}}}{D \mathrm{k}_{\mathrm{a}}+\left(l_{c}-D\right) \mathrm{k}_{\mathrm{f}}}\right)
$$

where $l_{c}=\frac{1}{\sqrt{N}}$.

Equation 1 gives the conductivity in the direction $\mathrm{y}$ within a hair layer formed by hairs oriented to the $\theta$ direction, but as the hairs of an actual hair coat were randomly oriented (Kowalski, 1978) an average $\mathrm{k}_{\mathrm{ef}}$ value (from values obtained with equation 1 for all directions) can be given by:

$$
\mathrm{k}_{\mathrm{ef}}=0,5\left(\mathrm{k}_{1}+\mathrm{k}_{\mathrm{p}}\right)
$$

However, radiative transfer through the coat $\left(\mathrm{k}_{\mathrm{r}}, \mathrm{mW} \cdot \mathrm{m}^{-1} \cdot \mathrm{K}^{-1}\right)$ is not considered in equation 7 , because $\mathrm{k}_{\mathrm{r}}$ can be estimated by theoretical calculations (Cena \& Monteith, 1975ab) in which the thermal conductivity of the coat due to the radiation is defined as:

$$
\mathrm{k}_{\mathrm{r}}=\frac{4 b}{3 P}
$$

where $b=4 \sigma \overline{\mathrm{T}}_{c}^{3}$; $\sigma$ is the Stefan-Boltzman constant (5.67051 $\times 10^{-8} \mathrm{~W} \cdot \mathrm{m}^{-2} \cdot \mathrm{K}^{-1}$ ) and $\overline{\mathrm{T}}_{\mathrm{c}}$ is the temperature within the hair layer. Cena \& Monteith (1975b) demonstrated that the $b$ value increases from $5.7 \mathrm{~W} \cdot \mathrm{m}^{-2} \cdot \mathrm{K}^{-1}$ for $\overline{\mathrm{T}}_{\mathrm{c}}=293 \mathrm{~K}$ to 7.0 $\mathrm{W} \cdot \mathrm{m}^{-2} \cdot \mathrm{K}^{-1}$ for $\overline{\mathrm{T}}_{\mathrm{c}}=313 \mathrm{~K}$. Of course, if the maximum temperature difference through the hair coat is less than $20 \mathrm{~K}$, then $b$ can have a value defined by a mean temperature $\overline{\mathrm{T}}_{\mathrm{c}}$. Then, a value $\overline{\mathrm{T}}_{\mathrm{c}}=303 \mathrm{~K}$ was assumed and consequently $b=6.3097 \mathrm{~W} \cdot \mathrm{m}^{-2} \cdot \mathrm{K}^{-1}$.

Cena $\&$ Monteith (1975a) defined $P$ as the fraction of the radiant energy that is intercepted by a unit hair thickness:

$$
\mathrm{P}=N D(\tan \theta \mathrm{f})
$$

Consequently, $\mathrm{k}_{\mathrm{r}}$ can be determined by:

$$
\mathrm{k}_{\mathrm{r}}=\frac{8,4129}{N D\left(\tan \theta_{\mathrm{f}}\right)}
$$

Finally, by combining equations 6 and 9 the thermal conductivity of the coat due to the conduction and the radiation through the hair layer can be estimated as:

$$
\mathrm{k}_{\mathrm{ef}}=0,5\left(\mathrm{k}_{1}+\mathrm{k}_{\mathrm{p}}\right)+\mathrm{k}_{\mathrm{r}}
$$

The data were analysed by the least squares method (Harvey, 1960) using the Statistical Analysis System
(SAS, version 6.1). The model used for the thermal conductivity of the coat was:

$$
y_{i j k l m}=\mu+m_{i}+i_{j}+s_{k}+c_{l}+\varepsilon_{i j k l m}
$$

where $y_{i j k l m}$ is the effective thermal conductivity of the hair coat of the $m$-th cow of the $j$-th age class, sired by the sire of $k$-th origin, considering the $l$-th coat colour, measured in the $i$-th month; $m$ is the fixed effect of the $i$-th month of observation; $i$ is the fixed effect of the $j$-th age class; $s$ is the random effect of the $k$-th origin sire origin; $c$ is the fixed effect of the $l$-th coat colour; $\mu$ is the overall mean and $\varepsilon$ is the random error.

The Restricted Maximum Likelihood (REML) method was used for the univariate analyses to estimate variance components and genetic parameters in an animal model, by means of the MTDFREML package.

The matrix model was:

$$
\mathrm{y}=\mathrm{Xb}+\mathrm{Za}+\mathrm{e}
$$

where $y$ is the $n_{i} x 1$ vector of de $n_{i}$ observations in the cows; $X$ is the $n_{i} x p$ incidence matrix of the p levels of fixed effects; $b$ is the $\mathrm{p} x 1$ vector of fixed effects and covariates; $Z$ is the $n_{i} \times n_{i}$ block diagonal incidence matrix of the genetic values, with dimensions $\mathrm{n} \mathrm{x} \mathrm{q}$ for random effects per animal; a is the $\mathrm{q} x 1$ vector of animal random effects; $\mathrm{e}$ is the $\mathrm{n} \mathrm{x} 1$ vector of random errors, in which $\mathrm{q}$ is the number of random effect levels and $p$ is the number of levels of fixed effects and covariates.

Assumptions for model 13 were $\mathrm{E}(\mathrm{y})=\mathrm{Xb}$ and $E(a)=E(e)=0$, in which the effect of the error (including genetic, environmental and non-additive genetic effects) is independently distributed with variance $\sigma^{2}$. Therefore, $\operatorname{var}(\mathrm{e})=\mathrm{I} \sigma_{\mathrm{e}}^{2}=\mathrm{R}$; $\operatorname{var}(\mathrm{a})=\mathrm{A} \sigma^{2}=\mathrm{A}$ a and $\operatorname{cov}(\mathrm{a}, \mathrm{e})=0$, where A is the relationship matrix of the animals; I is the identity matrix; $\sigma_{\mathrm{a}}^{2}$ ia the direct additive variance of the traits; $\sigma_{\mathrm{e}}^{2}$ residual variance of the traits. As $\operatorname{cov}(\mathrm{a}, \mathrm{e})=0$, then $\mathrm{ZAZ}$.

The mixed model (12) can be represented as:

$$
\left[\begin{array}{cc}
\mathbf{X}^{\prime} \mathbf{X} & \mathbf{X}^{\prime} \mathbf{Z} \\
\mathbf{Z}^{\prime} \mathbf{X} & \mathbf{Z}^{\prime} \mathbf{Z}+\mathbf{A}_{\mathbf{a}}^{-\mathbf{1}}
\end{array}\right]\left[\begin{array}{l}
\hat{\mathbf{b}} \\
\hat{\mathbf{a}}
\end{array}\right]=\left[\begin{array}{c}
\mathbf{X}^{\prime} \mathbf{Y} \\
\mathbf{Z}^{\prime} \mathbf{Y}
\end{array}\right]
$$

where $\mathrm{a}=\sigma_{\mathrm{e}}^{2} / \sigma_{a}^{2}$ or $\left(1-\mathrm{h}^{2}\right) / \mathrm{h}^{2}$, in which heritability coefficient is $\hat{\mathrm{h}}^{2}=\left(\sigma_{\mathrm{a}}^{2} / \sigma_{f}^{2}\right)$. Other terms were defined previously.

\section{Results and Discussion}

The coat morphological characteristics and the characteristics of the black and white coats were different 
(Maia et al. 2005) (Table 1). The white coat was denser with long, thin hairs, while the black coat was less dense with short, thick hairs. The average thermal conductivity of the hair coat was $49.72 \mathrm{~mW} \cdot \mathrm{m}^{-1} \cdot \mathrm{K}^{-1}$ (Table 2), a value lower than the range of 76 to $147 \mathrm{~mW} \cdot \mathrm{m}^{-1} \cdot \mathrm{K}^{-1}$ recorded by Bennett (1964) and Davis \& Birkebak (1974). On the other hand, Cena \& Monteith (1974b) suggested that expected values for the thermal conductivity of hair coats in the absence of free convection were between 30 and $45 \mathrm{~mW} \cdot \mathrm{m}^{-1} \cdot \mathrm{K}^{-1}$. The value $\mathrm{k}_{\mathrm{ef}}=49.72 \mathrm{~mW} \cdot \mathrm{m}^{-1} \cdot \mathrm{K}^{-1}$ observed in the present study would be attributed mainly to the area occupied by the hairs, which was $\rho_{\mathrm{ef}} / \rho_{\mathrm{f}}=17.8 \%$ only. This implies a variation between 25 and $29 \mathrm{~mW} \cdot \mathrm{m}^{-1} \cdot \mathrm{K}^{-1}$, close to the thermal conductivity of the air $\left(26 \mathrm{~mW} \cdot \mathrm{m}^{-1} \cdot \mathrm{K}^{-1}\right)$; in other words, about $71 \%$ of $\mathrm{k}_{\text {ef }}$ were due to $\mathrm{k}_{\mathrm{l}}$.

The fraction of the surface area that was effectively occupied by the hairs at a given distance from the skin $\left(\rho_{\text {ef }} / \rho_{f}\right)$ was significantly higher $(P<0.05)$ in the white than in the black coat (Table 2). This result was related to the number of hairs per unit area, greater in the white coat

Table 1 - Four hair coat characteristics in Holstein cows bred in a tropical environment. Values adjusted for coat colour

\begin{tabular}{lccr}
\hline Item & \multicolumn{2}{c}{ Coat colour } & \multirow{2}{*}{ Mean } \\
\cline { 2 - 4 } & Black & White & 1946 \\
Number of observations & 973 & 973 & $0.255 \pm 0.0011$ \\
Hair coat thickness $(\mathrm{cm})$ & $0.24 \mathrm{~b} \pm 0.0024$ & $0.28 \mathrm{a} \pm 0.0024$ & $1.31 \pm 0.008$ \\
Hair length $(\mathrm{cm})$ & $12.97 \mathrm{~b} \pm 0.16$ & $15.13 \mathrm{a} \pm 0.16$ & $1,112 \pm 10$ \\
Number (hairs $\left./ \mathrm{cm}^{2}\right)$ & $921 \mathrm{~b} \pm 21$ & $1,296 \mathrm{a} \pm 21$ & $0.00620 \pm 0.000013$ \\
Hair diameter $(\mathrm{cm})$ & $0.0062 \mathrm{a} \pm 0.000028$ & $0.0059 \mathrm{~b} \pm 0.000028$ &
\end{tabular}

Means with the letter, for the same effect and between black or white column, do not differ (P>0.05) by the Tukey test.

Source: Maia et al. (2005).

Table 2 - Coat characteristics and hair coat thermal conductivity in Holstein cows bred in a tropical environment. Values adjusted for coat colour

\begin{tabular}{|c|c|c|c|}
\hline \multirow[t]{2}{*}{ Item } & \multicolumn{2}{|c|}{ Coat colour } & \multirow[t]{2}{*}{ Mean } \\
\hline & Black & White & \\
\hline Number of observations & 973 & 973 & 1946 \\
\hline $\begin{array}{l}\text { Fraction of the surface area that is occupied by hairs at } \\
\text { a given distance from the skin }\left(\rho_{\mathrm{ef}} / \rho_{\mathrm{f}}\right)\end{array}$ & $0.172 \mathrm{~b} \pm 0.0045$ & $0.213 a \pm 0.0045$ & $0.178 \pm 0.0021$ \\
\hline $\begin{array}{l}\text { Thermal conductivity in a direction perpendicular to } \\
\text { the hair axis, } \mathrm{k}_{\mathrm{p}}\left(\mathrm{mW} \cdot \mathrm{m}^{-1} \cdot \mathrm{K}^{-1}\right)\end{array}$ & $26.07 b \pm 0.029$ & $26.37 \mathrm{a} \pm 0.029$ & $26.21 \pm 0.013$ \\
\hline $\begin{array}{l}\text { Thermal conductivity in a direction parallel to the } \\
\text { hair axis, } \mathrm{k}_{1}\left(\mathrm{~mW} \cdot \mathrm{m}^{-1} \cdot \mathrm{K}^{-1}\right)\end{array}$ & $65.47 \mathrm{~b} \pm 1.05$ & $75.16 \mathrm{a} \pm 1.05$ & $66.99 \pm 0.50$ \\
\hline Effective thermal conductivity, $\mathrm{k}_{\mathrm{ef}}\left(\mathrm{mW} \cdot \mathrm{m}^{-1} \cdot \mathrm{K}^{-1}\right) \mathrm{k}_{\mathrm{ef}}$ & $49.25 b \pm 0.048$ & $53.15 \mathrm{a} \pm 0.048$ & $49.72 \pm 0.022$ \\
\hline
\end{tabular}

Means with the letter, for the same effect and between black or white column, do not differ (P>0.05) by the Tukey test.

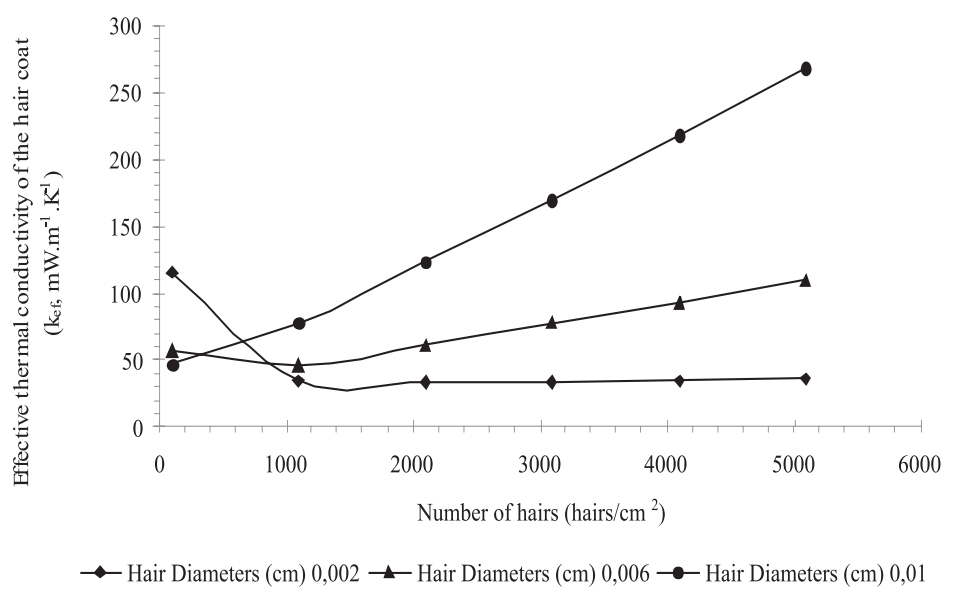

Figure 2 - Effective thermal conductivity of the hair coat in Holstein cows in relation to the number of hairs and associated to three hair diameters, hair length.

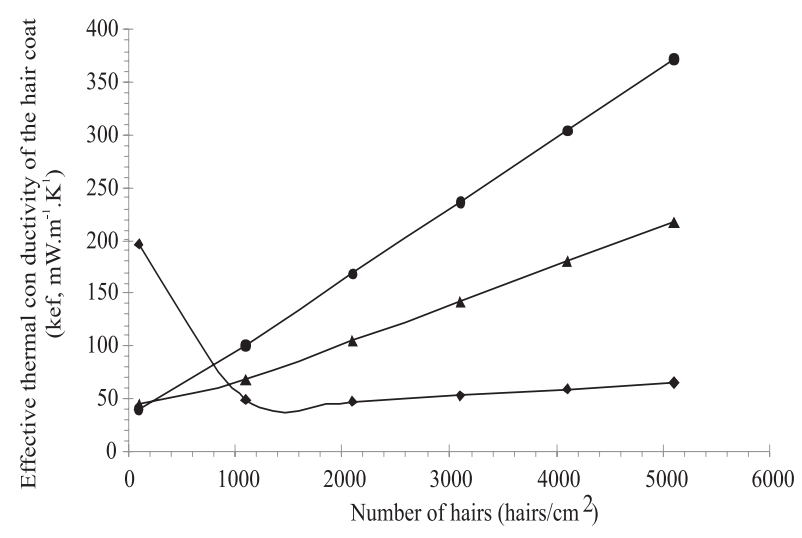

$\rightarrow$ Hair Length $(\mathrm{cm})$ 0,3 $\rightarrow$ Hair Length $(\mathrm{cm})$ 1,8 $\rightarrow$ Hair Length $(\mathrm{cm}) 3,3$

$$
\text { hair diameters, hair length. }
$$


(1,296 hairs $\left./ \mathrm{cm}^{2}\right)$; these hairs are also longer (Table 1$)$. The fact that the denser coat had the longest hairs explained why the thermal conductivity of the white coat was greater $(\mathrm{P}<0.05)$ than that of the black coat (Table 2).

The number of hairs (Figure 2) increased together with the hair diameter (above $0.006 \mathrm{~cm}$ ) there was a significant increase in the effective thermal conductivity of the hair coat. In fact, $\mathrm{k}_{\mathrm{ef}}$ reached a value of $270 \mathrm{~mW} \cdot \mathrm{m}^{-1} \cdot \mathrm{K}^{-1}$ when $\mathrm{N}=5,000$ hairs $/ \mathrm{cm}^{2}$ and $\mathrm{D}=0.01 \mathrm{~cm}$. The result was reversed when $\mathrm{Dd} \leq 0.002 \mathrm{~cm}$.

The increase in the number of hairs when associated to increased hair length $(\mathrm{C}>1.8 \mathrm{~cm})$ favoured the increase in $\mathrm{k}_{\mathrm{ef}}$. The value of $\mathrm{k}_{\mathrm{ef}}$ is $370 \mathrm{~mW} \cdot \mathrm{m}^{-1} \cdot \mathrm{K}^{-1}$ for $\mathrm{N}=5,000$ and $\mathrm{C}=3.3 \mathrm{~cm}$; however, if $\mathrm{C} \leq 0.5 \mathrm{~cm}$, the effective thermal conductivity has an inverse relationship with the number of hairs. The increase in the hair diameter in association with hair lengths over $1.8 \mathrm{~cm}$ caused increase in $\mathrm{k}_{\mathrm{ef}}$ (Figure 3), but opposite results occurred when $\mathrm{C}=0.3 \mathrm{~cm}$.

It is possible to increase the $\mathrm{k}_{\mathrm{ef}}$ value in two ways (Figure 2). In the first case, $\mathrm{N}>1,000, \mathrm{C}>2.0 \mathrm{~cm}$ and $\mathrm{D}>0.05$ $\mathrm{cm}$ and we have a dense coat consisting of long, thick hairs. The results of Maia et al. (2002) showed a high positive genetic correlation of the hair length and hair diameter with coat thickness. The conclusion was that the selection of animals in that direction would increase the thermal resistance of the hair coat - because the resistance is proportional to the coat thickness.

However, if such a result is advantageous in a cold environment, it is detrimental in a tropical climate. In the second case a reverse selection would be applied; i.e., for

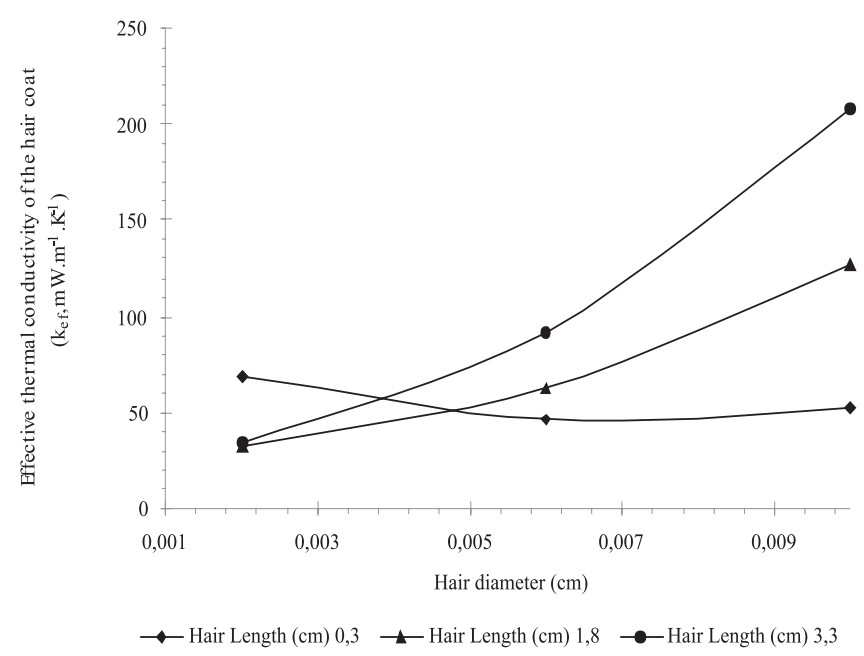

Figure 3 - Effective thermal conductivity of the hair coat in Holstein cows in relation to the diameters of hair and associated to three values of hair length. less dense coats $\left(<500\right.$ hairs $\left./ \mathrm{cm}^{2}\right)$ with short $(<1 \mathrm{~cm})$, thin $(<0.003 \mathrm{~cm})$ hairs. The results of Maia et al. (2005) showed an inverse relationship of hair number with the effective transmittance of the coat. In other words, the smaller the $\mathrm{N}$ value, the greater the probability a photon would run through the hair coat and strike the skin. In such a case the animals must present a highly pigmented skin for protection against ultraviolet radiation.

The heritability coefficient of $\mathrm{k}_{\mathrm{ef}}$ was $\mathrm{h}^{2}=0.18$ (Table 3 ), by which it is possible to select the animals for greater values of heat transfer through the hair coat. The model used to calculate $\mathrm{k}_{\mathrm{ef}}$ (Kowalski 1978) was also used by other authors (Gebremedhin et al., 1981; 1997; Jiang et al., 2005), but does not take into consideration the heat transfer by convection within the hair coat. However, the effect of that fact is hitherto unknown on the final value of $k_{e f}$. New models must be developed in order to calculate $\mathrm{k}_{\mathrm{ef}}$ by taking convection transfer into consideration.

The selection direction is also questioned: (a) for denser coats with longer, thicker hairs or (b) less dense coats with short, thin hairs. Based on the $\mathrm{k}_{\text {ef }}$ values obtained by the model by Kowalski (1978) and Cena \& Monteith (1975) under the assumption of high solar radiation levels, selection would be made for animals with less dense coats with short, thin hairs over a highly pigmented skin. On the other hand, non-pigmented skins must be covered by a dense coat with long, thick hairs.

Table 3 - Genetic parameters estimated for the effective thermal conductivity $\left(\mathrm{k}_{\mathrm{ef}}\right)$ of the hair coat in Holstein cows

\begin{tabular}{lc}
\hline Parameter & $\mathrm{k}_{\mathrm{ef}}$ \\
\hline$\sigma_{\mathrm{a}}^{2}$ Additive genetic variance & 13.14 \\
$\sigma_{\mathrm{e}}^{2}$ Environmental and non-additive genetic variance & 59.90 \\
$\sigma_{\mathrm{f}}^{2}$ Phenotypic variance & 73.04 \\
$\mathrm{~h}^{2}$ Heritability coefficient & $0.18 \pm 0.033$ \\
\hline
\end{tabular}

\section{Conclusions}

The value of the effective thermal conductivity of the hair coat was low, but greater for white coats because of its greater density. The heritability coefficient of the effective thermal conductivity showed a moderate value and pointed to the possibility of selection for increased heat transfer through the hair coat. More efficient models are needed to estimate the effective thermal conductivity of hair coats, by taking into consideration the heat transfer by convection within the hair coat. 


\section{Literature Cited}

BENNetT, J.W. Thermal insulation of cattle coats. Proceedings of the Australian Society Animal Production, n.5, p.160-166, 1964.

CENA, K.; MONTEITH, J.L. Transfer processes in animal coats. I. Radiative transfer. Proceedings of the Royal of Society London, B Biological Sciences, v.188, n.1, p.377-393, 1975a. CENA, K.; MONTEITH, J.L. Transfer processes in animal coats. II. Conduction and convection. Proceedings of the Royal of Society London, B Biological Sciences, v.88, n.1, p.395-411, 1975b.

DAVIS, L.B.; BIRKEBAK, R.C. On the transfer of energy in layers of fur. Biophysical Journal, v.14, p.249-268, 1974.

GEBREMEDHIN, K.G.; PORTER, W.P.; CRAMER, C.O. Quantitative analysis of the heat exchange through the fur layer of Holstein calves. Transactions of the ASAE, v.26, n.1, p.188-193, 1983.

GEBREMEDHIN, K.G.; NI, H.; HILLMAN, P.E. Modeling temperature profile and heat flux through irradiated fur layer. Transactions of the ASAE, v.40, n.5, p.1441-1447, 1997.
HARVEY, W.R. Least-Squares analysis of data with unequal subclass numbers. Beltsville: USDA, 1960 (Publ. $n^{\circ}$ 20-8).

JIANG, M.; GEBREMEDHIN, K. G.; ALBRIGHT, L.D. Simulation of skin temperature and sensible and latent heat losses through fur layers. Transactions of ASAE, v.48, n.2, p.767-775, 2005.

KOWALSKI, G.J. An analytical and experimental investigation of the heat loss through animal fur. 1978. Thesis (Ph.D. in Mechanical Engineering) - University of Wisconsin, Madison, 1978. 306p.

MAIA, A.S.C.; SILVA, R.G.; BERTIPAGLIA, E.A. Características do pelame de vacas Holandesas em ambiente tropical. Um estudo genético e adaptativo. Revista Brasileira de Zootecnia, v.32, n.4, p.843-853, 2003.

MAIA, A.S.C.; SILVA, R.G.; BERTIPAGLIA, E.A. Environmental and genetic variation of the effective radiative properties of the coat of Holstein cows under tropical conditions. Livestock Production Science, v.92, p.307-315, 2005.

SILVA, R.G. Introdução à bioclimatologia animal. São Paulo: Nobel, 2000. 286p.

STATISTICAL ANALYSIS SYSTEM - SAS. SAS User's guide: Statistics. Cary: 2001. 956p. 